\title{
Epilogue. On Augusta's porch; a meditation on decolonizing the archives
}

\author{
Jeannette A. Bastian ${ }^{1}$ (D)
}

Published online: 15 May 2019

(C) Springer Nature B.V. 2019

For most of my adult life, I have made my home on the island of St. Thomas in the United States Virgin Islands. The Virgin Islands, like other islands in the Caribbean Antillean archipelago, was part of that seventeenth- and eighteenth-century land grab by European countries looking to expand their empires and fill their coffers through colonization, exploitation and enslaved labour. My perspective on colonialism, de-colonialism and their relationship to archives and records is through this lens of the Caribbean. As part of my perspective, I offer this personal story:

It is a warm and sunny Sunday afternoon in St. Thomas, Virgin Islands and I am sitting on Augusta's porch. Augusta is my 99-year old mother-in-law. Born on the island of St. John, the smallest of the three Virgin Islands, she has lived in St. Thomas for most of her very long life. She traces her St. Johnian family back many generations.

Many of Augusta's children and their children also live on St. Thomas and every Sunday afternoon after church, various members of this extended family gather on her porch. They bring food and share a meal together. They play dominoes, a popular game throughout the Caribbean. It is a game at which Augusta excels and often wins - to the great chagrin of her younger partners. This Sunday I am privileged to be part of this gathering - an assortment of aunts, uncles, grandchildren and great grandchildren including Augusta's 99-year old cousin and the cousin's daughter and granddaughter.

The conversation swirls around as comfortable family meetings usually do, touching on many topics until it finally focuses on the spelling of a family name, Dalmida - is it an I or a Y, an E or an A. Why do some members of the family from nearby islands or from different generations spell that name differently? Other names are thrown into the mix- for this really is a very large family. Several theories are broached, some rejected, no-one really knows the answer, but everyone has a theory.

Jeannette A. Bastian

bastian@simmons.edu

1 Simmons University, 300 The Fenway, Boston, MA 02115, USA 
Suddenly someone calls out - 'maybe the answer is in those old Danish records, in the Archives' - we all know what she means - it's common knowledge among Virgin Islanders that the colonizing Danes took their records with them when they sold the islands to the Americans and left in 1917. That possibility is seriously considered but then rejected because as everyone also knows, those records are in Denmark or possibly locked up in the Virgin Islands - certainly locked up in an Archives somewhere. There is general agreement among the group that even if there is some information in those records, there is no way to find out - those records created in the then colony of the Danish West Indies are not easily accessible. A brief regret, but the conversation moves on. If the records aren't accessible, maybe they don't really matter anyway what we know and what we tell one another may be what matters and may be enough!

I take some lessons from this conversation on Augusta's porch: that records or the lack of records is a very personal matter; that for colonized or formerly colonized peoples, the shadow of the colonizer never quite goes away-that shadow can be slight, can be looming or may even be benign or nostalgic but it is present in some form; but that in spite of records or the absence of records, communities can and will choose how they wish to remember.

Is it ever really possible to decolonize the archives? Is it possible to set aside an archival tradition, or does the successful decolonized society re-craft the archives, turn the tradition inside out, demand that colonial tradition give way to the cultural expressions and unique records of the decolonized society? Perhaps when you finally stop worrying about those old colonial records, finally break free of that hold that those records have over you, when your colonial history is put firmly in the past-maybe in favour of a pre-colonial past-you truly decolonize yourself. But while that is easy to say about ephemeral issues like the spelling of a name, it may be impossible when those colonial records contain critical information about your family, yourself and your community.

Colonialism is not a monolith. Each formerly colonized territory, each currently marginalized community has suffered (still suffers) colonialism in its own way and each seeks its own path to self-expression and self-realization. How archives fit into that path-finding process is the subject of this journal issue. Each essay addresses the relationships between records and decolonialism from different perspectives, but they are united by their recognition of the agency of the archivist. Re-crafting and re-interpreting archival processes, re-purposing the records of the oppressor to benefit the oppressed, recognizing and legitimating alternate forms of recordsall lie within the purview of the archivist. Much has been written about the power of records, but these essays demonstrate that the power to decolonize the archives resides, at least partially, within archivists themselves.

Publisher's Note Springer Nature remains neutral with regard to jurisdictional claims in published maps and institutional affiliations. 
Jeannette A. Bastian is a Professor in the School of Library and Information Science, Simmons College, Boston, Massachusetts, where she directs their Archives Management program. A former Territorial Librarian of the United States Virgin Islands, she holds an M.Phil. from the University of the West Indies and a PhD from the University of Pittsburgh. Her books include West Indian Literature, A Critical Index, 1930-1975 (Allis, 1982), Owning Memory, How a Caribbean Community Lost Its Archives and Found Its History (2003), Community Archives, The Shaping of Memory, editor. (2009), Archives in Libraries; What Librarians and Archivists Need to Know to Work Together (2015), and Decolonizing the Caribbean Record, An Archives Reader (2018). 